International Journal of Current Microbiology and Applied Sciences

ISSN: 2319-7706 Volume 9 Number 9 (2020)

Journal homepage: http://www.ijcmas.com

Original Research Article

https://doi.org/10.20546/ijcmas.2020.909.262

\title{
Evaluation for Resistance of Cluster Bean Varieties against Alternaria Leaf Blight in vivo
}

\author{
Suresh Kumar*, A.K. Meena, Mohit Kumar and Kavita Rani \\ Department of Plant Pathology, College of Agriculture, Swami Keshwanand Rajasthan \\ Agricultural University, Bikaner (Rajasthan) 334 006, India \\ *Corresponding author
}

\begin{abstract}
A B S T R A C T
Keywords

Cluster bean,

Varieties, Alternaria

blight, Alternaria

cyamopsidis

Article Info

Accepted:

17 August 2020

Available Online:

10 September 2020

The sixteen varieties of cluster bean were screened against Alternaria blight of cluster bean caused by Alternaria cucumeriana var. cyamopsidis under field conditions at College Research Farm, College of Agriculture, Swami Keshwanand Rajasthan Agricultural University, Bikaner. Sixteen varieties screened against Alternaria blight under artificial inoculation conditions during Kharif 2016. Out of sixteen varieties of cluster bean, none was found highly resistant against Alternaria blight. Only one variety of RGC-986 was found resistant, whereas, five varieties viz., RGC-1003, HG-75, HGS-365, HGS-563, and GG-2 were found moderately resistant to Alternaria blight.
\end{abstract}

\section{Introduction}

The cluster bean [Cyamopsis tetragonoloba (L.) Taub], bushy annual herb have a deeprooted system, is a resilient and droughtresilient leguminous crop grown on sandy soils of arid and semi-arid regions Cluster bean is being grown in India since ancient time, Although believed to be of African origin (Vavilov, 1951). It was domesticated centuries ago in the north-western region of the Indo Pakistan sub-continent (Hymowitz, 1972). Cluster bean is a photosensitive crop and grown well in specific climatic conditions, which ensure a soil temperature around $21-25{ }^{\circ} \mathrm{C}$ for proper germination (Hymowitz and Matlock, 1963). It can be grown on a variety of soil types from loamy to sandy. Cluster bean is grown in India, Pakistan, Indonesia, America, Italy, Mexico, Brazil, and South Africa. India is the leading country in the world concerning area and production of guar, where it occupies 55.8 lakh hectares with an annual production of 27.51 million tonnes of seed (Anonymous, $2015-16)$. India produced 82 percent of total guar production in the world followed by Pakistan 15.6 percent and 2.4 percent USA, Brazil, and others. In India, this crop is mostly grown in the state of Rajasthan, Haryana, 
Punjab, Uttar Pradesh, and Madhya Pradesh. Rajasthan occupies 47.8 lakh hectares area with a production of 22.23 million tonnes with a productivity of $465 \mathrm{~kg} \mathrm{ha} \mathrm{ha}^{-1}$ (Anonymous, 2015-16). It has potential productivity of about $1500 \mathrm{~kg} \mathrm{ha}{ }^{-1}$. In Rajasthan, it is mainly grown in Barmer, Churu, Sriganganagar, Nagaur, Jalore, Sikar, Jaisalmer, Bikaner, Jaipur, Jhunjhunu, Hanumangarh, and Alwar districts.

The production and productivity of cluster bean in terms of grain and fodder is limited mostly due to the destructive fungal disease caused by Alternaria cucumerina var. cyamopsidis, it is a major foliar disease of cluster bean in northern India (Rangaswami and Rao, 1957). This disease alone has been reported to be responsible for a reduction in yield by 55.76 to 58.70 percent under artificial epiphytotic conditions (Gupta, 1994). The disease appears year after year in mild to severe form since the pathogen is seed-borne (Sowell, 1965). Alternaria blight is a major disease in North India. In the early stages of infection, the water-soaked spots appear on leaf blade which later turns grayish to dark brown with concentric zonations, demarcated with light brown lines inside the spot on the under surface. The time of appearance as well as the intensity of Alternaria blight varies from variety to variety, area to area, and one crop season to other. The information on various biochemical parameters imparting resistance to Alternaria blight will be helpful for the identification of resistant varieties based on biochemical attributes and these can be used as marker for screening of germplasm and other breeding material at the early stage for resistance to this disease. The knowledge of sources of resistance and inheritance of resistance is must carry out a systemic breeding programme for incorporating effective resistance gene (s) in promising genotypes. During favorable weather conditions for disease development, a very meager work has been carried out on weather parameters, which are responsible for disease development. There is a positive correlation between weather parameters favorable for the progressive development of disease in the crop. Although the effective control of the disease can be only possible through management aspects, in which the basic disease control parameters are fungicidal and botanical preparation.

\section{Materials and Methods}

This experiment, sixteen varieties, of cluster bean namely RGC-986, RGC-1003, HG-75, HGS-365, HGS-563， GG-2， RGC-1031, RGC-1002, RGC-1002, RGC-471, RGC-936, RGC-1017, RGC-1033, RGC-1038, RGC1055, HGS-870, HG-2-20, RGC-936 collected from different sources were sown in Kharif 2016 (20 ${ }^{\text {th }}$ July). Artificial inoculation was made after 45 days of sowing. Each test cultivar was sown in two rows of $3 \mathrm{~m}$ length with a row to row spacing $30 \mathrm{~cm}$ and randomly sown one row of a known susceptible check (RGC-936). The recommended package of practices was followed to raise the normal crop. The observations on initiation and development of disease were recorded at 50 percent pod formation stage using 0-5 scale.

The disease index on foliage was calculated using the formula of McKinney (1923).

Sum of all numerical ratings

Percent Disease Intensity = $\mathrm{x} 100$

Total number of leaves observed $x$ Maximum disease grade 


\section{Results and Discussion}

The varieties under the study were scored for their reaction to the disease on $0-5$ scale and categorized as highly resistant (HR), resistant (R), moderately resistant (MR), moderately susceptible (MS), susceptible (S) and highly susceptible (HS). The maximum disease intensity was observed in RGC-936 (79.06\%) followed by RGC-471 (69.30\%) and RGC1017 (66.20\%). Similarly, the minimum disease intensity was recorded in RGC-986 $(4.85 \%)$ and GG-2 (8.41\%).

Out of sixteen varieties, none was found free from Alternaria blight disease. However, one variety RGC-986 was found resistant $(\mathrm{R})$. The five varieties viz., RGC-1003, HG-75, HGS365, HGS-563, GG-2 were assessed as moderately resistant (MR). The one variety RGC-1031 was categorized as moderately susceptible (MS) and another one variety RGC-1002 was categorized as susceptible (S). Rest of eight varieties viz., RGC-471, RGC936, RGC-1017, RGC-1033, RGC-1038, RGC-1055, HGS-870, and HG-2-20 were grouped under highly susceptible (HS) category against Alternaria blight of cluster bean.

Similarly, trends were also found by Saharan and Saharan (2003). They observed that out of 186 varieties/genotypes tested under artificial inoculation conditions during Kharif 1997, none was found free from Alternaria blight. However, only five varieties viz., CAZG-9007, GAUG-9008, GAUG-9406, GAUG-9407, and RGC-1014 were found resistant to Alternaria blight of cluster bean. Among the rest of the genotypes, 73, 86, and 19 were accessed as moderately resistant (MR), under moderately susceptible (MS) and susceptible (S), respectively. The same categorized pattern was also used during Kharif 1998 in 83 cluster bean genotypes under artificial inoculation conditions. The results of the present studies are also in agreement with the findings of Shivanna and Shetty (1991) and Meena et al., (2010). Therefore, these lines can be used in future studies against Alternaria blight of cluster bean.

It is concluded that out of sixteen varieties of cluster bean screened during Kharif 2016, none was found highly resistant against Alternaria blight. Only one variety RGC-986 was found resistant, whereas, five varieties viz., RGC-1003, HG-75, HGS-365, HGS-563, and GG-2 were found moderately resistant to Alternaria blight.

Table.1 Rating scale for Alternaria leaf blight of cluster bean

\begin{tabular}{|c|c|c|c|}
\hline Rating Scale & Disease Reaction & $\begin{array}{c}\text { Per cent Disease } \\
\text { Intensity }\end{array}$ & Description \\
\hline $\mathbf{0}$ & Near immune/ Resistant reaction(I) & 0 & No symptoms \\
\hline $\mathbf{1}$ & Resistant (R) & $1-10$ & $1-10 \%$ leaf area infected \\
\hline $\mathbf{2}$ & Moderately Resistant (MR) & $11-25$ & $11-25 \%$ leaf area infected \\
\hline $\mathbf{3}$ & Moderately Susceptible (MS) & $26-50$ & $26-50 \%$ leaf area infected \\
\hline $\mathbf{4}$ & Susceptible (S) & $51-75$ & $51-75 \%$ leaf area infected \\
\hline $\mathbf{5}$ & Highly Susceptible (HS) & $76-100$ & $76 \%$ above leaf area Infected \\
\hline
\end{tabular}


Table.2 Reaction of cluster bean varieties to Alternaria cucumerina var. cyamopsidis under artificial in vivo

\begin{tabular}{|c|c|c|}
\hline Variety & Disease Intensity $(\boldsymbol{\%})$ & Disease reaction \\
\hline RGC-1003 & 8.85 & MR \\
\hline RGC-1033 & 63.97 & HS \\
\hline RGC-1002 & 41.73 & S \\
\hline RGC-1017 & 66.20 & HS \\
\hline RGC-1055 & 62.18 & HS \\
\hline RGC-1031 & 24.42 & MS \\
\hline HG-75 & 9.74 & MR \\
\hline GG-2 & 8.41 & MR \\
\hline HG-365 & 9.30 & MR \\
\hline HG-870 & 60.41 & HS \\
\hline RGC-1038 & 56.41 & HS \\
\hline HG-563 & 9.30 & MR \\
\hline HG-2-20 & 63.93 & HS \\
\hline RGC-986 & 4.85 & R \\
\hline RGC-471 & 69.30 & HS \\
\hline RGC-936 & 79.06 & \\
\hline
\end{tabular}

Table.3 Categorization of cluster bean varieties against Alternaria blight

\begin{tabular}{|l|l|}
\hline \multicolumn{1}{|c|}{ Varieties } & \multicolumn{1}{c|}{ Host reaction } \\
\hline RGC-986 (1) & Resistant (R) \\
\hline $\begin{array}{l}\text { RGC-1003, HG-75, HGS-365, HGS-563, GG-2 } \\
\mathbf{5})\end{array}$ & Moderately Resistant (MR) \\
\hline RGC-1031 (1) & Moderately Susceptible (MS) \\
\hline RGC-1002 (1) & Susceptible (S) \\
\hline $\begin{array}{l}\text { RGC-471, RGC-936, RGC-1017, RGC-1033, } \\
\text { RGC-1038, RGC-1055, HGS-870, HG-2-20 (8) }\end{array}$ & Highly Susceptible (HS) \\
\hline
\end{tabular}

\section{References}

Anonymous, 2015-16. Directorate of Agriculture. Agriculture Statistics. Government of Rajasthan, Jaipur.

Gupta, P. P. 1994. Assessment of yield losses in different genotypes of clusterbean against important diseases. Annual Report of All India Coordinated Research Project of Arid Legumes. pp. 1-14.
Hymowitz, T. 1972. The trans-demostication concept as applied to guar. Econ. Bot. 26: 49-60.

Hymowitz, T and Matlock, R. S. 1963. Guar in the United State, Oklahuma Agriculture Experiment Station, Tech. Bull. 611: 1-34.

McKinney, H.H.1923. Influence of soil temperature and moisture on infection of wheat seedling by Helminthosporium sativum. J. Agric. Res. 26: 195-217. 
Meena, A. K. Godara, S.L. and Gangopadhyay, S. 2010. Efficacy of fungicides and plant extracts against Alternaria blight of cluster bean. $J$. Mycol. Pl. Pathol. 40(2): 272-275.

Rangaswami, G and Rao, A. V. 1957. Alternaria blight of clusterbean [Cyamopsis tetragonoloba (L.) Taub]. Indian Phytopathol. 10: 13-18.

Saharan, M. S and Saharan, G. S. 2003. Sources of resistance in clusterbean to Alternaria blight disease (Alternaria cucumerima var. cyamopsidis). J.
Mycol. Pl. Pathol. 33(3), 453-455.

Shivanna, M. B. and Shetty, H. S. 1991. Reaction of selected clusterbean (Cyamopsis tetragonoloba) varieties to infection by Alternaria cyamopsidis and Colletotrichum dematium. Indian $J$. Agric. Sci. 61: 856-859.

Sowell, P.G. 1965. The effect of seed treatment on seed borne pathogens of guar. Pl. Dis. Reptr. 49: 895-897.

Vavilo, N. I., 1951. The origin, variation, immunity and breeding of cultivated plants. Chron. Bot. 13: 364.

\section{How to cite this article:}

Suresh Kumar, A.K. Meena, Mohit Kumar and Kavita Rani. 2020. Evaluation for Resistance of Cluster Bean Varieties against Alternaria Leaf Blight in vivo. Int.J.Curr.Microbiol.App.Sci. 9(09): 2107-2111. doi: https://doi.org/10.20546/ijcmas.2020.909.262 